\title{
Electrochemical Sensors Based on Modification of Carbon Fiber Microelectrode by Nickel Phthalocyanine Polymer for 3-Methyl-4-Nitrophenol Analysis in Water
}

\author{
Yibor Fabrice Roland Bako¹, Boukare Kabore'2, Issa Tapsoba ${ }^{1}$ \\ ${ }^{1}$ Laboratoire de Chimie Analytique, Environnementale et Bio-organique (LCAEBiO), Département de Chimie, \\ Université Ouaga 1 Pr Joseph Ki-Zerbo, Ouagadougou, Burkina Faso \\ ${ }^{2}$ Bureau des Mines et de la Géologie du Burkina (BUMIGEB), Ouagadougou, Burkina Faso \\ Email: issa.tapsoba@gmail.com
}

How to cite this paper: Bako, Y.F.R., Kabore, B. and Tapsoba I. (2017) Electrochemical Sensors Based on Modification of Carbon Fiber Microelectrode by Nickel Phthalocyanine Polymer for 3-Methyl-4-Nitrophenol Analysis in Water. Materials Sciences and Applications, 8, 798-810. https://doi.org/10.4236/msa.2017.811058

Received: August 24, 2017

Accepted: October 21, 2017

Published: October 24, 2017

Copyright (c) 2017 by authors and Scientific Research Publishing Inc. This work is licensed under the Creative Commons Attribution International License (CC BY 4.0).

http://creativecommons.org/licenses/by/4.0/

(c) (i) Open Access

\begin{abstract}
3-methyl-4-nitrophenol (MNP) is the main by-product of the organophosphate insecticide fenitrothion (FT), used in locust control. MNP is highly toxic because it is an endocrine disruptor and then may cause adverse in the biological systems. Then, it is necessary to develop analytical methods for determination of this pollutant in the environment. In this sense, we reported herein the development of an electrochemical sensor for the detection of 3-methyl-4-nitrophenol (MNP), one of the metabolites of fenitrothion (FT), by using naked and modified carbon fiber microelectrode (CFME) by nickel tetrasulfonated phthalocyanine polymer (CFME/p-NiTSPc). The voltammogram showed that MNP presents one irreversible anodic peak corresponding to the oxidation of the phenol group at $0.9 \mathrm{~V}$ vs $\mathrm{Ag} / \mathrm{AgCl}$. The effect of $\mathrm{pH}$ of the buffer on the peak current and SWV parameters such as frequency, scan increment and pulse amplitude were investigated in order to optimize the electrochemical response of the sensor. The obtained results lead to the following optimum value: $\mathrm{pH}=6$; frequency $=25 \mathrm{~Hz}$, pulse amplitude $=50 \mathrm{mV}$, scan increment $=10 \mathrm{mV}$. With these optimum values, the calibration curves show that the peak current varied linearly upon MNP concentration leading to a limit of detection (LoD) for naked CFME close to $3 \mu \mathrm{g} / \mathrm{L}$ whereas for CFME modified by $\mathrm{p}-\mathrm{NiTSP}$, it reaches $0.75 \mu \mathrm{g} / \mathrm{L}$. This results prove that the presence of $\mathrm{p}-\mathrm{NiTSP}$ increasing the sensitivity of the sensor could be used to monitor 3-methyl-4-nitro- phenol residue in real matrix.
\end{abstract}

\section{Keywords}

3-Methyl-4-Nitrophenol, Carbon Fiber Microelectrode, 
Nickel Tetrasulfonated Phthalocyanine Film, Cyclic Voltammetry, Square Wave Voltammetry

\section{Introduction}

The relentless pursue of improving productivity and agricultural products quality has led man to a massive use of pesticides. Thus, according to the United Nations Organization statistics Food and Agriculture Organization (FAO), in Burkina Faso over 500 tons of pesticides are used each year since 2010 [1]. Among them, fenitrothion, an organophosphate insecticide is widely used in cotton cultivation in the north of Burkina Faso in the fight against locust attack. It is well-known that it possesses some toxicity because it acts as acetylcholinesterase inhibitors and its residues and metabolites are present in food chain and environment [2] [3] [4] [5]. Thus, to limit the impact of pesticides on the environment and human health, analytical techniques have been developed to detect their presence and quantify pesticide residues in waters, soils, foods. The commonly used analytical methods are the high-performance liquid chromatography (HPLC), mass spectrometry (MS), gas chromatography (GC) or coupled techniques GC-MS and ELISA [3] [4] [6] [7]. However, these techniques require means huge, skilled technicians, very long analysis time, a step of sample pretreatment and they are not suitable for analysis of organophosphate pesticides due to their instability. Simple and advantageous alternatives are electrochemical techniques due to their low cost, high sensitivity and specificity and they do provide fast and reliable analysis [2] [3] [4] [8] [9]. Several studies reported that organophosphate compounds can be detected electrochemically using CFME [5] [10] [11] and CFME modified by use of polymers, enzymes and mercury to improve their sensitivity and selectivity [6] [7] [12] [13]. In previous work, we report the use of CFME modified by nickel tetrasulfonated phthalocyanine polymer (p-NiTSPc) film for methylparathion and its metabolite p-nitrophenol in water [7]. We report herein the electrochemical modification of CFME by p-NiTSPc for the detection 3-methyl-para-nitrophenol (MNP), one of the stable by-product of fenitrothion in water.

\section{Experimental}

\subsection{Apparatus and Chemicals}

All electrochemical measurements were performed using a portable potentiostat (Palmsens) controlled by software and obtained through International Foundation for Science (IFS) individual grant.

3-methyl-4-nitrophenol (MNP), as a powder with analytical grade, was purchased from Sigma-Aldrich, and a stock solution $(5 \mathrm{mg} / \mathrm{L})$ was prepared in distilled water. Phosphate buffer solution (PBS) $0.2 \mathrm{M}$ was used as supporting electrolyte and prepared by mixing appropriate amounts of potassium phosphate 
monobasic $\left(\mathrm{KH}_{2} \mathrm{PO}_{4}\right)$ and potassium phosphate dibasic $\left(\mathrm{K}_{2} \mathrm{HPO}_{4}\right)$ in MilliQ water. NiTSPc monomers were purchased by Sigma and used as received.

Platinum electrode $(250 \mu \mathrm{m})$ and $\mathrm{Ag} / \mathrm{AgCl} / \mathrm{KCl} 1 \mathrm{M}$ were used as counter and reference electrodes respectively. The working electrode was a naked carbon fiber microelectrode (CFME) (diameter $\Phi=12 \mu \mathrm{m}$ ) or modified by p-NiTSPc film (p-NiTSPc/CFME) and all chemical are purchasing from Sigma Aldrich and are used without further purification.

\subsection{Analytical Procedure}

Electrochemical behavior of MNP at naked and modified carbon fiber microelectrode was investigated using cyclic voltammetry. Square wave voltammetry, which is well-known to be more sensitive has been used to analyze the amount of MNP in aqueous samples by following the irreversible oxidation peak. Phosphate buffer at $\mathrm{pH} 6$ containing $2 \mathrm{mM}$ of $\mathrm{Fe}(\mathrm{CN})_{6}{ }^{4-}$ was scanned in cyclic voltammetry $(\mathrm{CV})$ for electrochemical characterization of the performance of naked and modified working electrodes.

\subsection{Electrochemical Modification of CFME}

Prior to modification the working electrode was cleaned electrochemically in 0.5 $\mathrm{M} \mathrm{H}_{2} \mathrm{SO}_{4}$ with ethanol (1:1, v/v) by performing 10 cyclic voltammograms at the scan rate $50 \mathrm{mV} / \mathrm{s}$. After cleaning, the working electrode was modified following the method already reported [14]. Shortly: electropolymerization is first initiated by performing 5 cyclic voltammograms in $0.1 \mathrm{M}$ aqueous $\mathrm{NaOH}$ in the potential range 0 to $1.3 \mathrm{~V}$ and at the scan rate $100 \mathrm{mV} / \mathrm{s}$. The $\mathrm{p}-\mathrm{NiTSPc}$ is electrodeposited by performing 50 cyclic voltammograms in $2 \mathrm{mM} \mathrm{NiTSPc}$ aqueous solution prepared in $\mathrm{NaOH} 0.1 \mathrm{M}$, in the same potential range. After the polymerization, the modified electrode is cleaned in distillated water and a cyclic voltammogram is performed in $\mathrm{NaOH} 0.1 \mathrm{M}$ aqueous solution to highlight the effectiveness of the modification which will be confirmed by the presence of a reversible peak at $0.4 \mathrm{~V}$ vs ECS corresponding to the redox couple $\mathrm{Ni}^{\mathrm{III}} / \mathrm{Ni}^{\mathrm{II}}$.

\subsection{Scanning Electronic Microscopy (SEM) Images of the CFME}

SEM experiments were performed on CFME and CFME modified with p-NiTSPc (CFME/p-NiTSPc) using a JEOL type JSM-6301F (SCIAM, Angers university). Images obtained were from secondary electrons under 3 - $5 \mathrm{keV}$ with magnifications situated between 3000 and 5000. Figure 1 shows the surface morphology of the CFME and CFME/p-NiTSPc.

\section{Results and Discussions}

\subsection{Voltammetric Behavior of MNP on CFME}

Cyclic voltammogram of $30 \mathrm{mg} / \mathrm{L}$ of MNP in PBS $0.2 \mathrm{M} \mathrm{pH} 6$ at the scan rate of $50 \mathrm{mV} / \mathrm{s}$ is presented in Figure 2.

As it is illustrated on Figure 2, one can observe that MNP presents one 


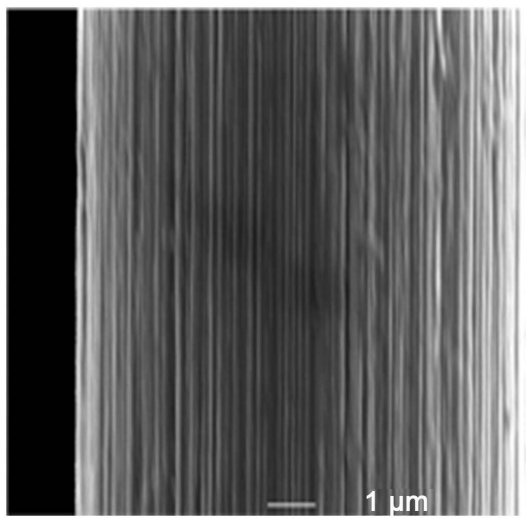

(a)
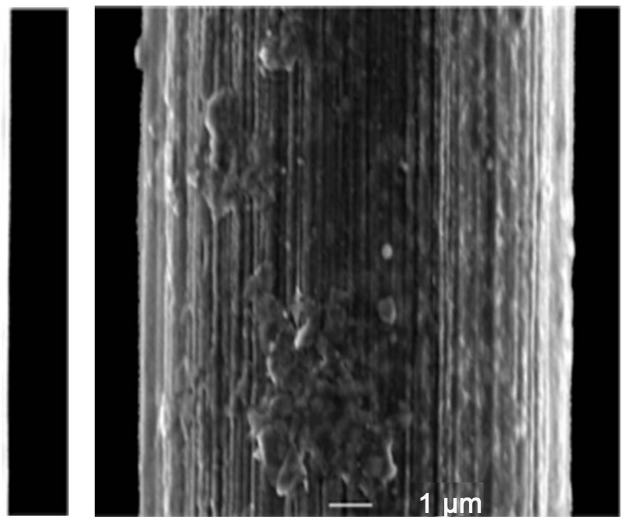

(b)

Figure 1. SEM images of CFMEs: (a) unmodified; (b) modified with $50 \mathrm{CV}$ of p-NiTSPc electrodepositon in alkaline solution ( $\mathrm{NaOH} 0.1 \mathrm{M}$, NiTSPc $2 \mathrm{mM}$, scan rate $100 \mathrm{mV} / \mathrm{s}$ ).

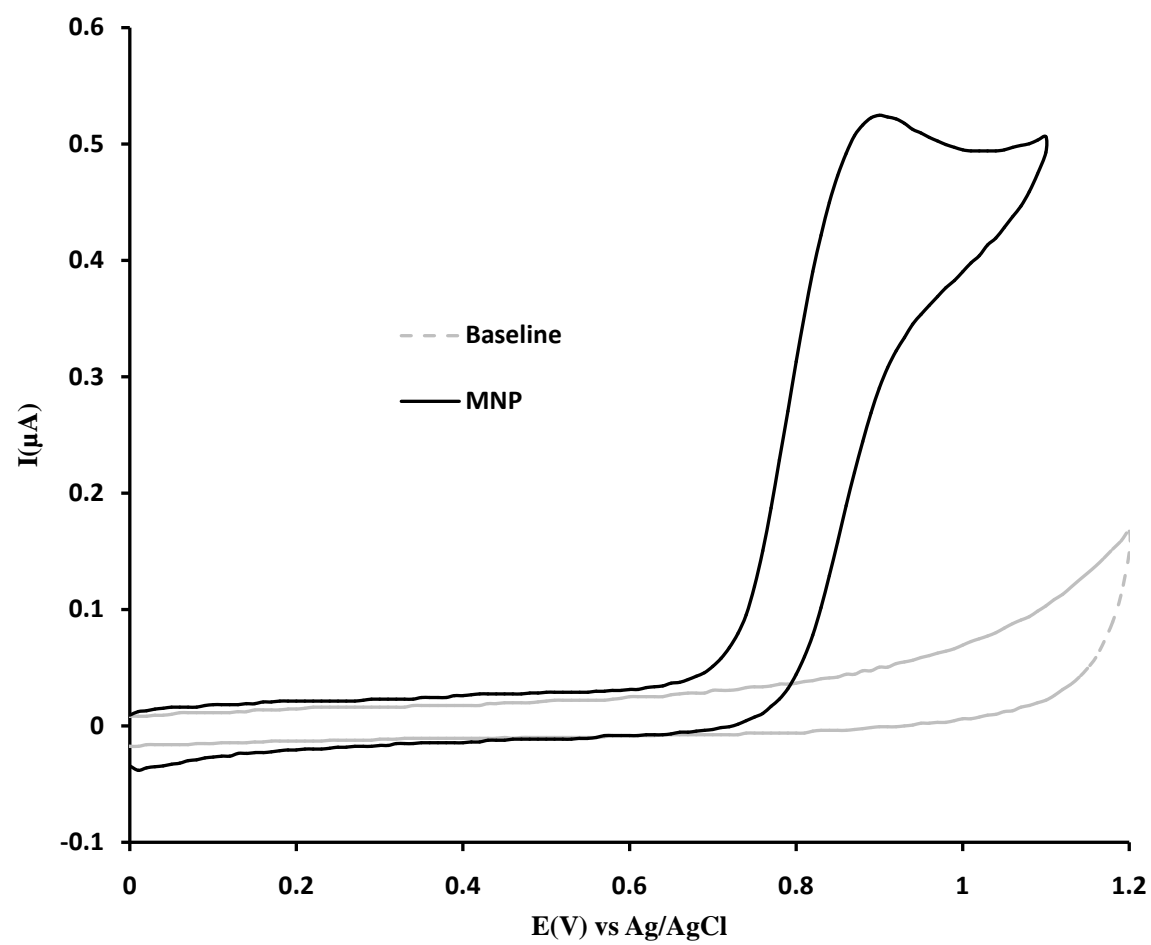

Figure 2. Cyclic voltammogram of $30 \mathrm{mg} / \mathrm{L}$ MNP in PBS $\mathrm{pH} 7$ at naked CFME $(\Phi=12$ $\mu \mathrm{m}$ ) versus $\mathrm{Ag} / \mathrm{AgCl} / \mathrm{Cl}^{-} 1 \mathrm{M}$ at the scan rate $\mathrm{v}=50 \mathrm{mV} / \mathrm{s}$.

ireversible oxidation peak at around $0.90 \mathrm{~V}$ versus $\mathrm{Ag} / \mathrm{AgCl} / \mathrm{KCl} 1 \mathrm{M}$ in comparison with the blank. This peak could be assigned to the oxidation of the phenol group and the irreversibility is due to the existence of chemical reaction following the electron transfer. This result is in agreement with the literature data [5] [7].

When cyclic voltammetry is realized on FT during scanning potential in cathodic domain (Figure 3), one can observe the presence of an irreversible peak at $-0.79 \mathrm{~V}$ vs $\mathrm{Ag} / \mathrm{AgCl} / \mathrm{KCl} 1 \mathrm{M}$ corresponding to 4 electrons transfer to nitro group [3] [4] [9] [15]. This result agrees with previous work on the electrochemical detection of methylparathion and its metabolite [7]. 


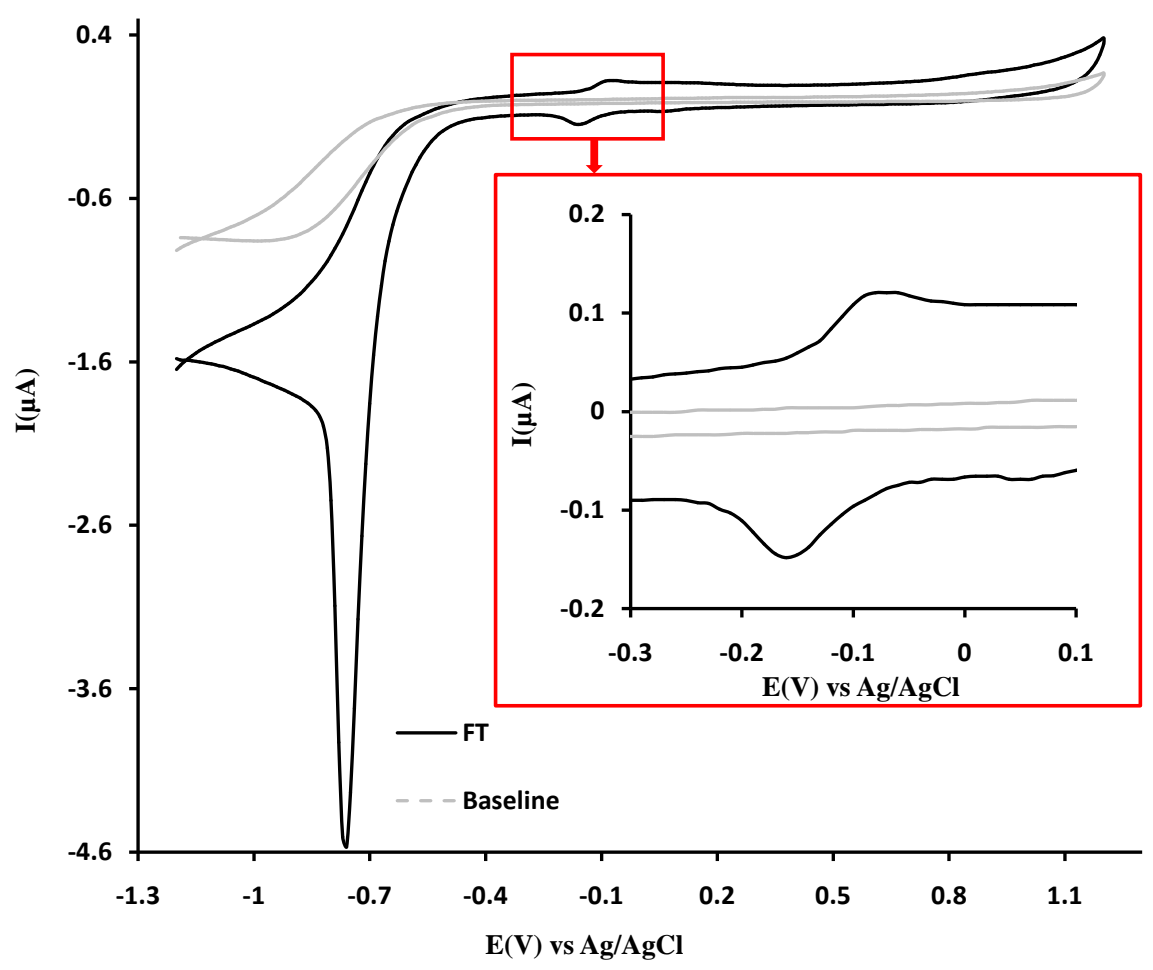

Figure 3. Cyclic voltammogram in PBS $0.2 \mathrm{M} \mathrm{pH} 7$ on CFME at the scan rate $100 \mathrm{mV} / \mathrm{s}$ of $30 \mathrm{mg} / \mathrm{L} \mathrm{FT}$.

During the reverse scan, one may note the presence of reversible peak at -0.05 $\mathrm{V}$ vs $\mathrm{Ag} / \mathrm{AgCl} / \mathrm{KCl} 1 \mathrm{M}$ corresponding to the oxidation/reduction of hydroxylamine electrogenerated to nitroso group and this agrees with the literature [4]. Due to the presence of nitro group on MNP, the electrochemical behavior in cathodic domain indicates (figure not shown) that MNP exhibits one irreversible peak corresponding in comparison with the literature, to electron transfer on nitro group.

Based on these results, on may conclude that FT and its metabolite MNP could be differentiate in anodic domain by the oxidation of phenol group. To improve the detection of the residues of MNP in environment, we carried out by square wave voltammetry (SWV), the effects some parameters such as the $\mathrm{pH}$ value and the electrochemical parameters of the method on the electrochemical oxidation of MNP using naked and modified CFME.

\subsection{Optimum Conditions for Analytical Method}

To optimize the electrochemical response of MNP by square wave voltammetry (SWV), the effect of $\mathrm{pH}$ of the buffer and the electrochemical parameters method (SWV) such as frequency, pulse increments and pulsation were investigated. Figure 4 represents the voltammograms of MNP on naked CFME using different $\mathrm{pH}$ 's value of PBS.

As illustrated on Figure 4, one can note that the anodic peak potential shifts to cathodic values when the $\mathrm{pH}$ increases from 2 to 7 . The representation of the 


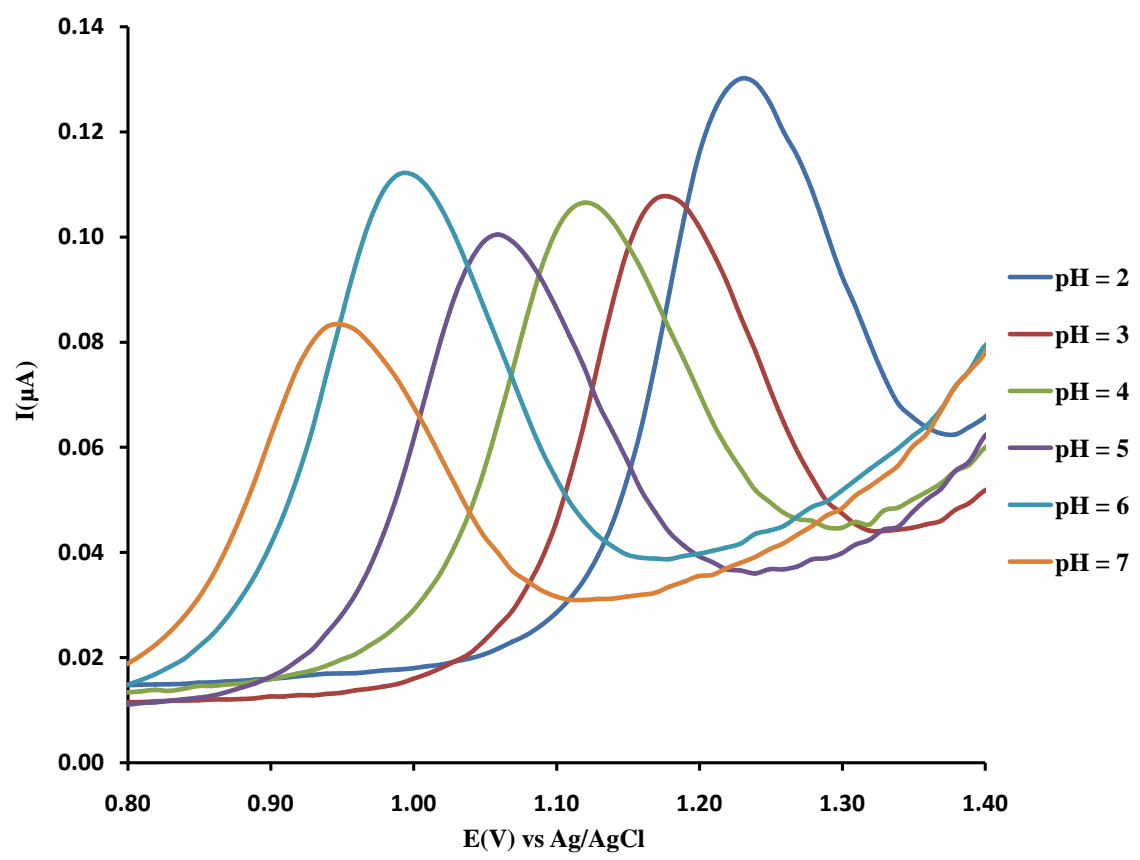

(a)

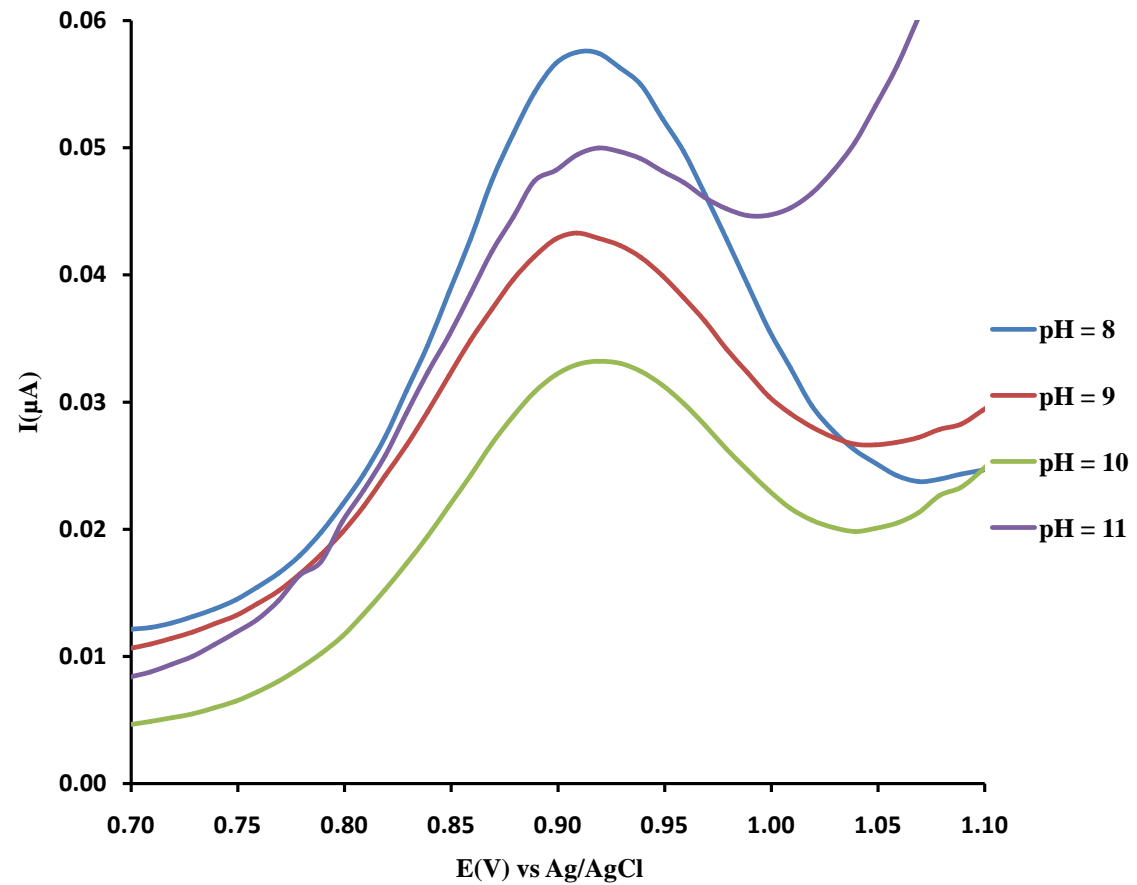

(b)

Figure 4. Square wave voltammograms of CFME in PBS of various $\mathrm{pHs}$ containing MNP $10 \mathrm{mg} / \mathrm{L}$.

peak potential upon $\mathrm{pH}$ value shows a linear decrease of the oxidation peak potential with the increase of the $\mathrm{pH}$ value from 2 to 7 (Figure 5). This behavior could be explained by the deprotonation of phenol group upon the increase of the $\mathrm{pH}$. The slope of the straight line close to $57 \mathrm{mV}$ per decade of $\mathrm{pH}$ agrees of one proton transferring, leading to the production of phenolate ions, more rich 


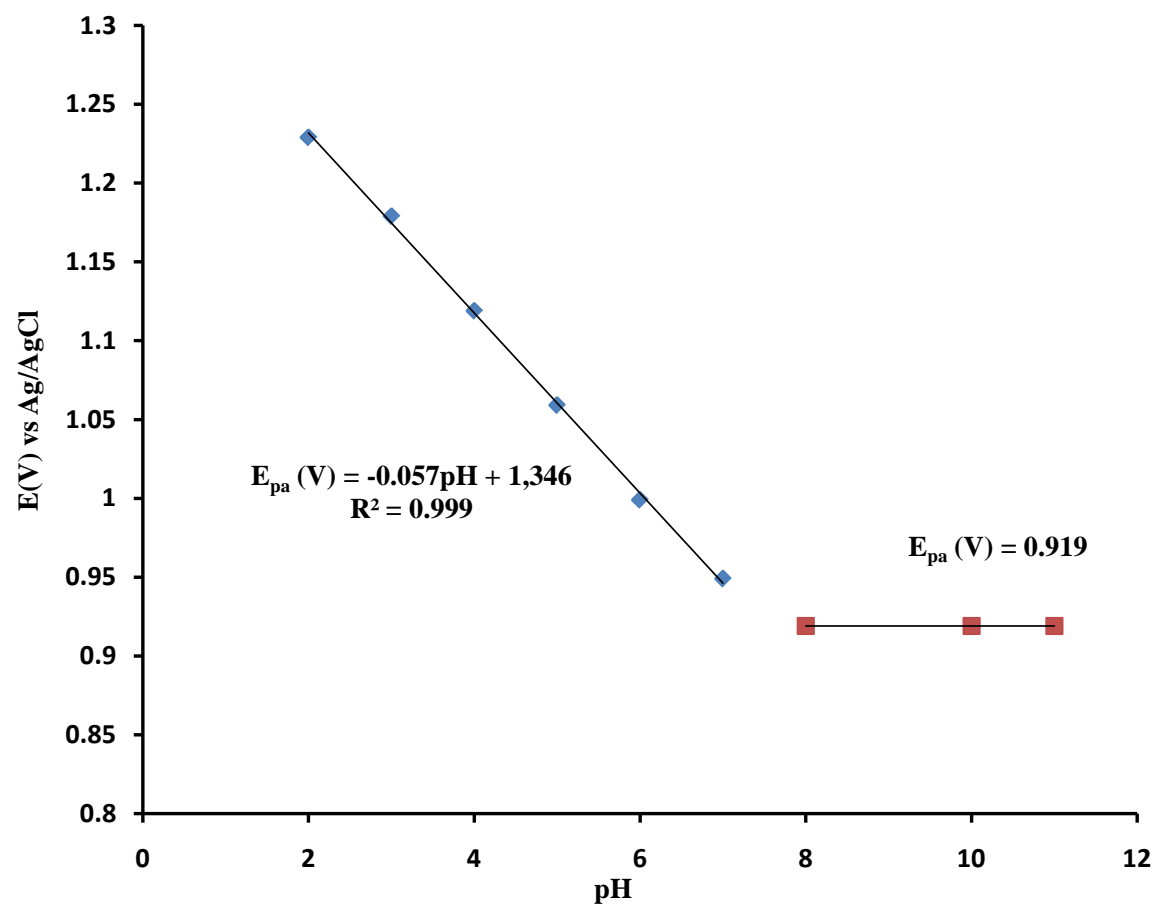

Figure 5. Oxidative peak potential vs phosphate buffer $\mathrm{pH}$ from 2 to 11 containing 10 $\mathrm{mg} / \mathrm{L} \mathrm{MNP}$ at CFME. Reference electrode: $\mathrm{Ag} / \mathrm{AgCl} / \mathrm{KCl} 1 \mathrm{M}$.

in electrons than phenol and therefore more easily oxidable. This result agrees with the literature [16]. Moreover, in the range of $\mathrm{pH} 8$ to 11, the peak potential remains constant (Figure 5) and this could be explained by the electron transfer on phenolate derivatives as reported elsewhere [16]. From these data, one can determine the acidity constant of MNP which is close to $\mathrm{pKa}=7.49$. Furthermore, the representation of peak current vs. $\mathrm{pH}$ (figure not shown) showed that the peak current presents a maximum at $\mathrm{pH} 6$.

The optimum parameters for determination of the electrochemical response of MNP by poising the optimum $\mathrm{pH}$ value on CFME have been determined by using SWV. The optimum values obtained are a frequency of $25 \mathrm{~Hz}$, a pulse amplitude of $50 \mathrm{mV}$ and a scan increment of $10 \mathrm{mV}$. Therefore, these optimum values are being used in the rest of the work.

\subsection{SWV for the Quantitative Analyzes of MNP on CFME}

Figure 6(a) shows square wave voltammograms of MNP in a concentration range $10 \mu \mathrm{g} / \mathrm{L}$ to $1 \mathrm{mg} / \mathrm{L}$ using the optimum parameters and the $\mathrm{pH}$ value of 6 . One can note that the peak current increase upon the increase of the concentration according to literature [8]. The representation of peak current intensity vs. concentration is illustrated on Figure 6(b). It is clear that the peak current is a linear function of concentration. Thus, in a concentration range 10 to $100 \mu \mathrm{g} / \mathrm{L}$ the relationship obtained is $I_{p a}(\mu \mathrm{A})=0.0006 C(\mu \mathrm{g} / \mathrm{L})+0.0007$ with regression coefficient $r^{2}=0.984$, while in a concentration range $100 \mu \mathrm{g} / \mathrm{L}$ to $1 \mathrm{~g} / \mathrm{L}$ the relationship is $I_{p a}(\mu \mathrm{A})=0.0002 C(\mu \mathrm{g} / \mathrm{L})+0.053$ with regression coefficient 


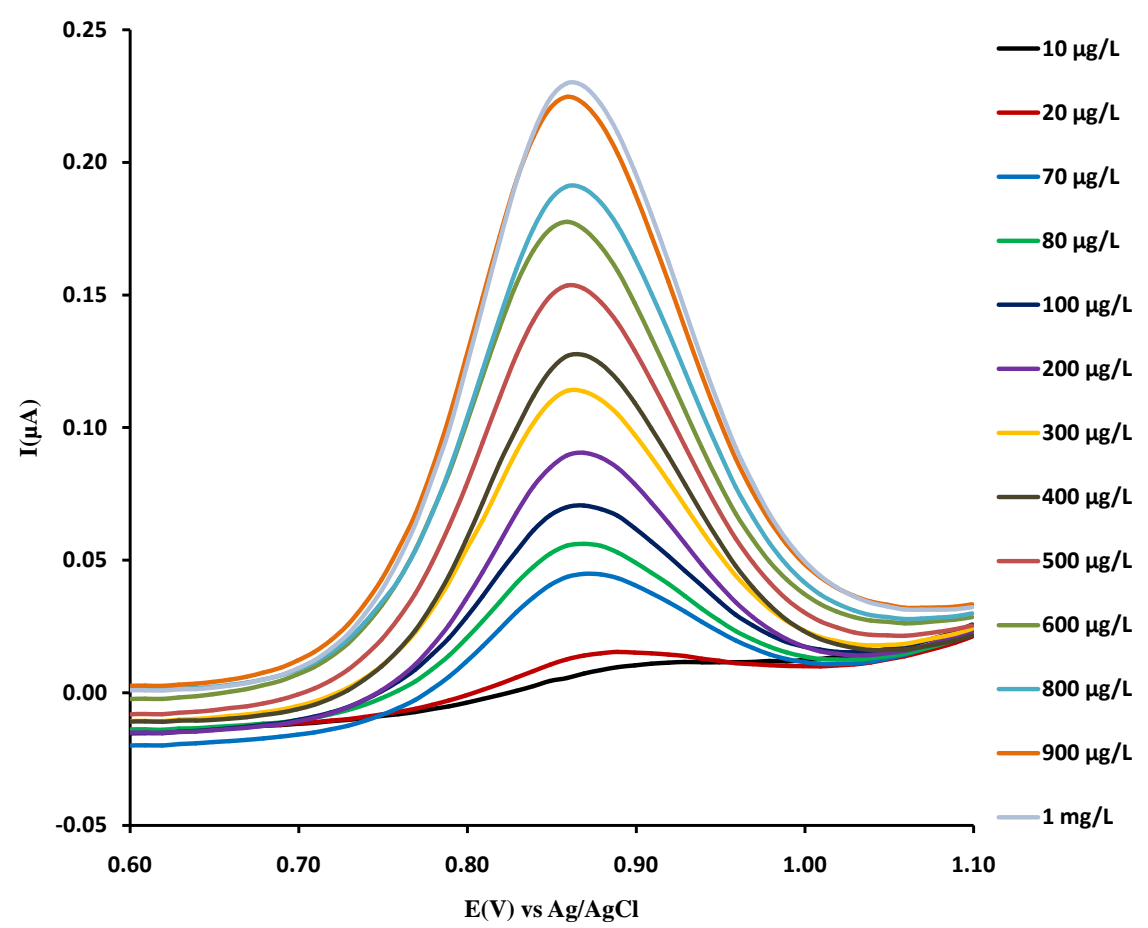

(a)

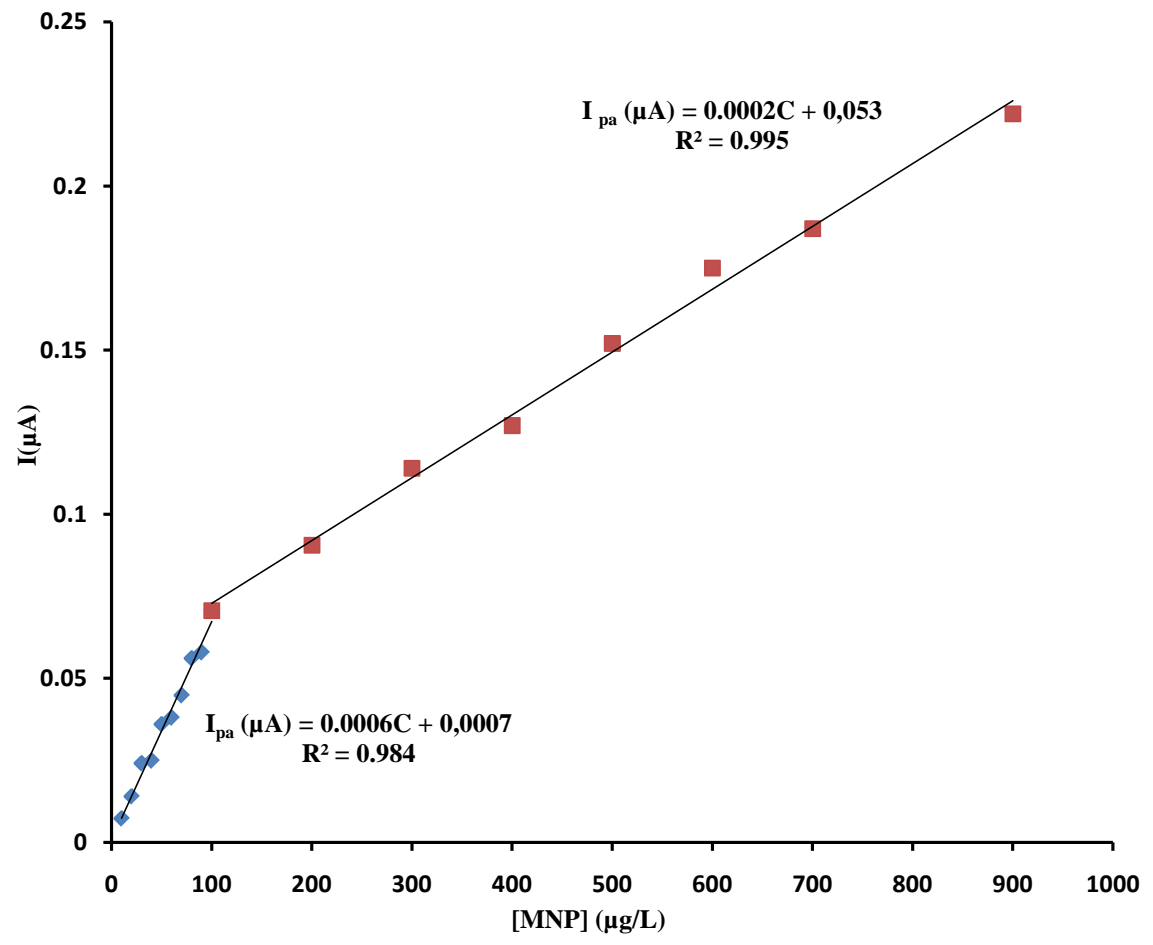

(b)

Figure 6. (a) Square Wave voltammograms of MPNP for different concentration in PBS $\mathrm{pH}$ 6. Concentration range: $10 \mu \mathrm{g} / \mathrm{L}$ to $1000 \mu \mathrm{g} / \mathrm{L}$; (b) Plot of peak current vs concentration of MPNP.

$\mathrm{r}^{2}=0.995$. Electrochemical method sensitivity was evaluated by calculating the LoD and LoQ and the values obtained were respectively $3 \mu \mathrm{g} / \mathrm{L}$ and $10 \mu \mathrm{g} / \mathrm{L}$. 


\subsection{Improving Sensitivity of CFME by Modification with p-NiTSPc}

In order to improve the sensitivity CFME was modified with p-NiTSPc as previously described. Figure 7 shows voltammogram of modification process. It can be observed with cycle number that on the one hand, oxidation current of front solvent increases and on the other hand, from the third cycle, begins to appear of a pair of peaks at around $0.5 \mathrm{~V}$, where the intensities increase according to the number of cycles. According to the work reported by Ordaz and coworkers [17], the first stage is the oxidation of the $\mathrm{OH}^{-}$anions of the solution beyond $1 \mathrm{~V}$ to produce $\mathrm{OH}$ radicals which lead to the functionalization of the electrode surface. This stage is followed by the formation of oxo bridges with the NiTSPc macro complex (second stage). Thus, the immobilized complex is electroactive due to the presence of cation $\mathrm{Ni}(\mathrm{II})$ and give rise to the appearance of a redox pair, visible from the third cycle of the potential sweep to around $0.5 \mathrm{~V}$, when enough film is formed on the surface of the electrode (third stage).The film thus formed continues to grow by the oxidation of new $\mathrm{OH}^{-}$anions of the solution, producing new layers by means of oxo bridges (fourth stage), this being demonstrated, with the general growth of the peaks observed on the voltammogram of Figure 7. To demonstrate catalytic effect of p-NiTSPc, CV was performed in $2 \mathrm{mM}$ aqueous solution using CFME and CFME/p-NiTSPc and the voltammogram obtained are illustrated on Figure 8. It can be seen in this picture that the resulting signal with CFME/p-NiTSPc is more intense than that obtained with CFME.

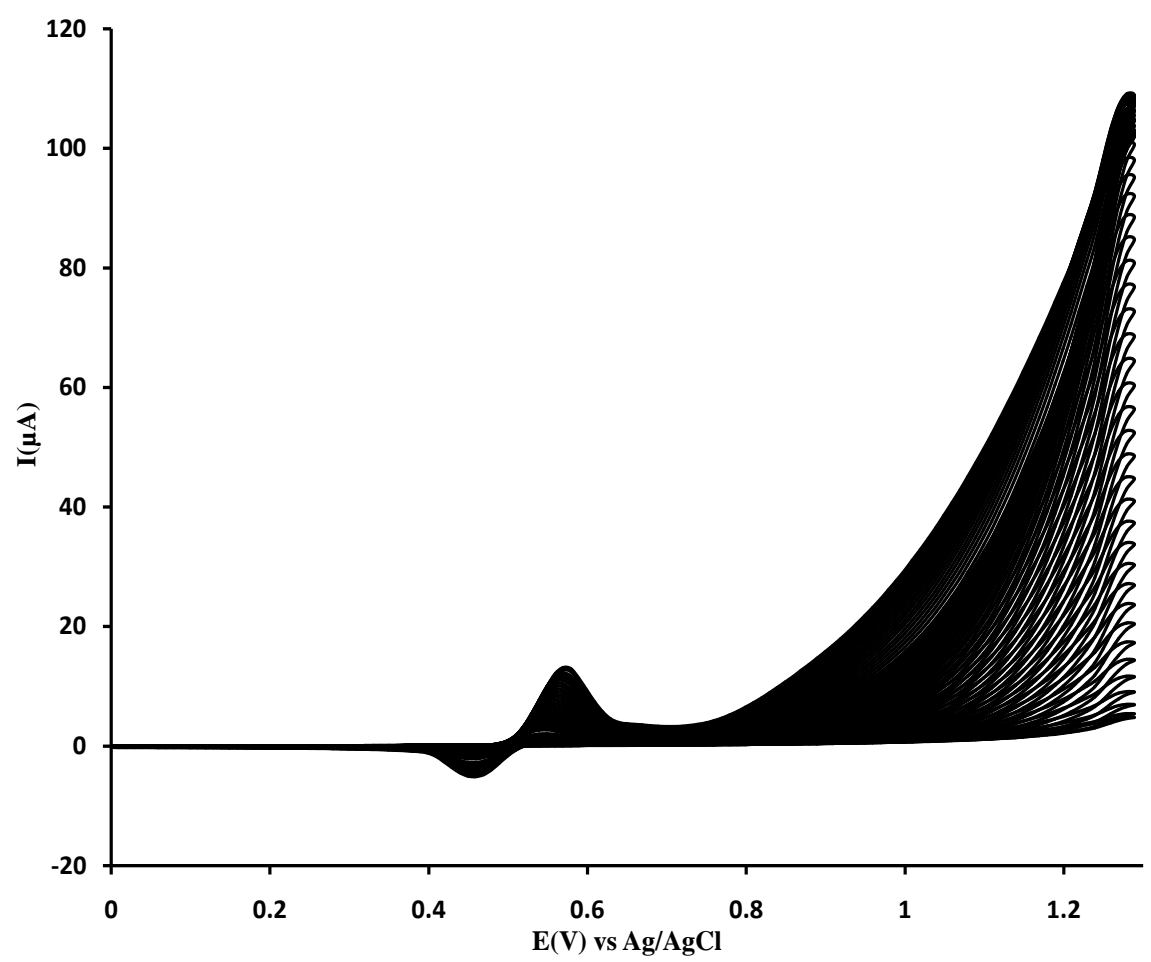

Figure 7. $2 \mathrm{mM}$ NiTSPc cyclic voltammograms in $0.1 \mathrm{M} \mathrm{NaOH}$ at CFME (successive cycle number $=50$; potential scan rate $\left.=50 \mathrm{mV} \cdot \mathrm{s}^{-1}\right)$. 


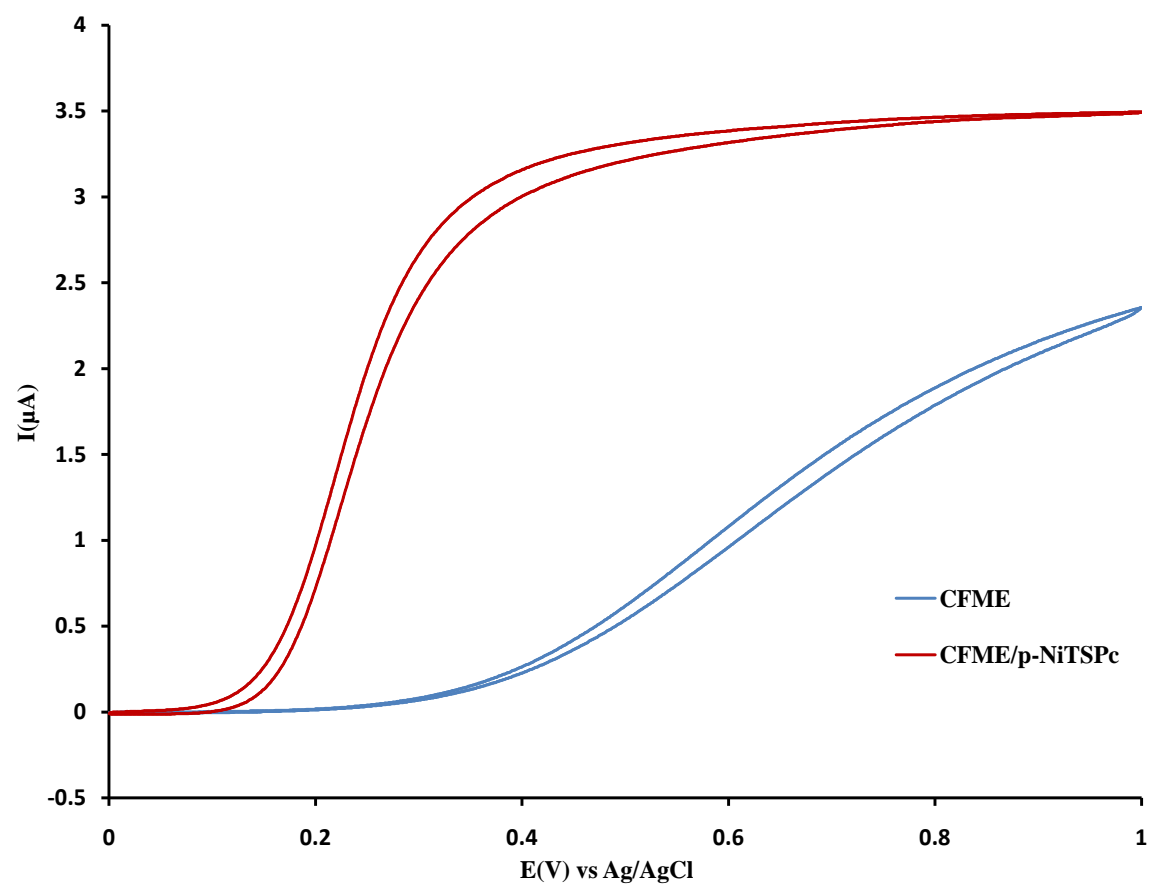

Figure 8. Voltammetric behavior of CFME/p-NiTSPc in PBS $\mathrm{pH}=6$ containing $2 \mathrm{mM}$ (potential scan rate $=50 \mathrm{mV} \cdot \mathrm{s}^{-1}$ ).

As with the CFME, effect of $\mathrm{pH}$ on peak current intensity and peak potential and SWV parameters were investigated with CFME/p-NiTSPc and the results are similar to that obtained previously. Current peak is maximum at $\mathrm{pH} 7$ and the optimum parameters obtained for determination of MNP on CFME/p-NiTSPc are frequency $=25 \mathrm{~Hz}$, pulse amplitude $=50 \mathrm{mV}$, scan increment $=10 \mathrm{mV}$ (data not showed). In such optimal conditions, SW voltammograms of MNP for different concentration using CFME/p-NiTSPc are presented in Figure 9(a). Exploitation of results (Figure 9(b)) brings up two regions were peak current increases linearly with concentration, as observed previously on CFME. Thus, in a concentration range 10 to $100 \mu \mathrm{g} / \mathrm{L}$ the relationship obtained is

$I_{p a}(\mu \mathrm{A})=0.004 C(\mu \mathrm{g} / \mathrm{L})-0.076$ with regression coefficient $\mathrm{r}^{2}=0.988$, while in concentration range $100 \mu \mathrm{g} / \mathrm{L}$ to $1 \mathrm{mg} / \mathrm{L}$ the relationship is

$I_{p a}(\mu \mathrm{A})=0.0006 C(\mu \mathrm{g} / \mathrm{L})+0.302$ with regression coefficient $\mathrm{r}^{2}=0.995$. Establishing a comparison between results obtained with CFME and CFME/p-NiTSPc, it is observed that the slope of calibration curve obtained with CFME/p-NiTSPc is more pronounced than that obtained with CFME in the two concentration ranges. The LoD was calculated and value obtained is $0.75 \mu \mathrm{g} / \mathrm{L}$. Thus, when comparing slope of analytical curves or LoDs, one can note clearly that sensitivity of CFME was increased by modification with p-NiTSPc.

In addition, we studied the reproducibility and stability of the sensor and the obtained results (Data not shown) shown that these sensors remained reproducible and stable. Indeed after 4 weeks of storage in laboratory temperature $\left(25^{\circ} \mathrm{C}\right)$, it lost only $5 \%$ of its response. 


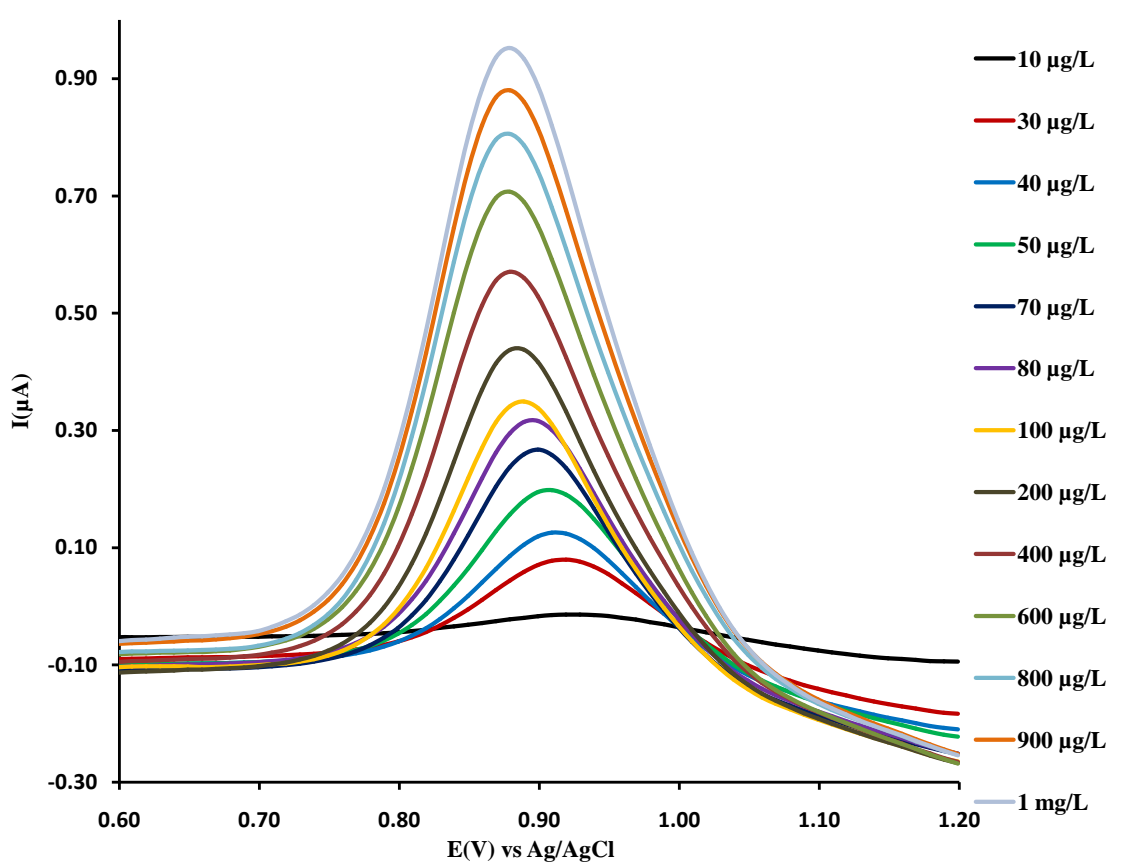

(a)

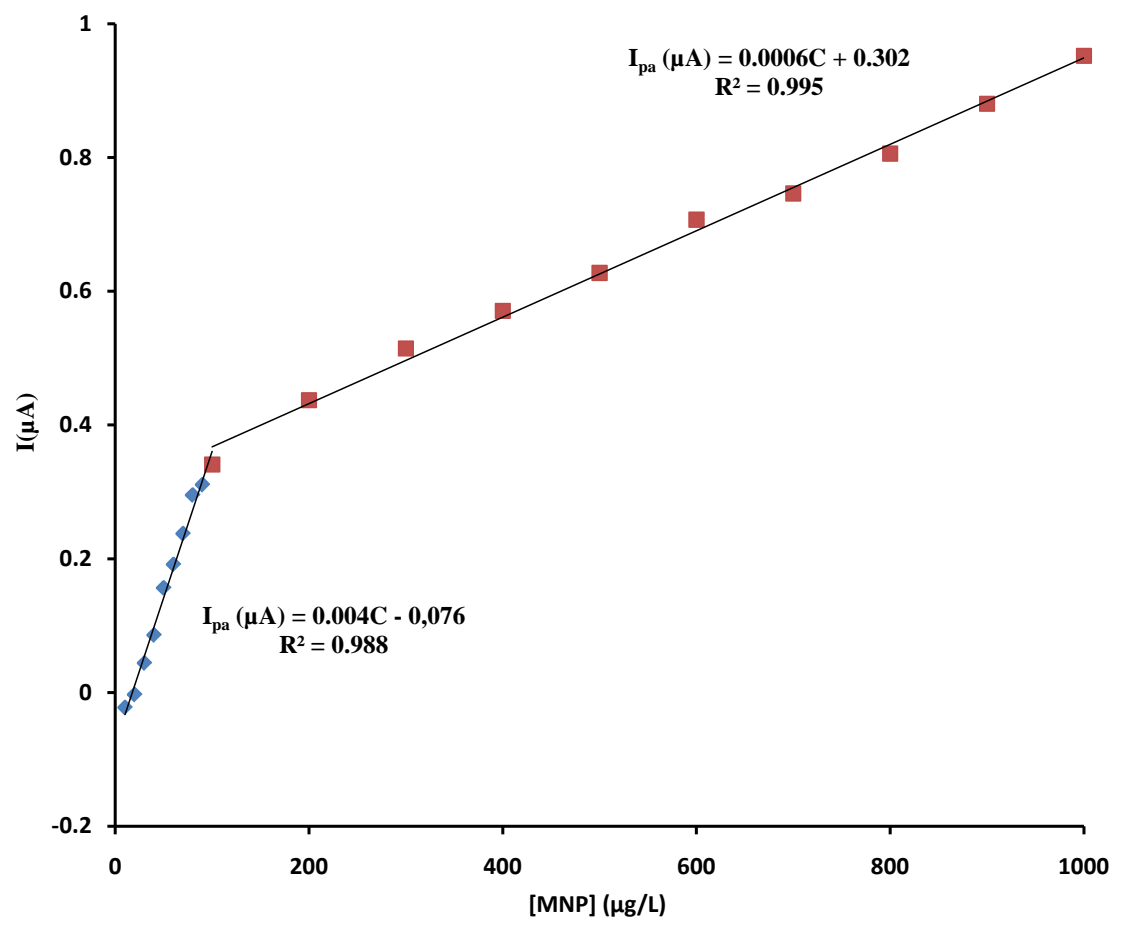

(b)

Figure 9. (a) Square Wave voltammograms of MPNP for different concentration in PBS pH 6. Concentration range: $10 \mu \mathrm{g} / \mathrm{L}$ to $1000 \mu \mathrm{g} / \mathrm{L}$; (b) Plot of peak current vs concentration of MPNP.

\section{Conclusion}

MNP determination was performed using SWV and following the oxidative peak current of phenol group at naked CFME and modified CFME with p-NiTSPc. 
The effects of $\mathrm{pH}$ and SWV parameters (frequency, scan increment and pulse amplitude) were investigated and the pKa was estimated. Peak current varied linearly with concentration in two regions for both sensors. The LoD calculated for MNP on CFME is $3 \mu \mathrm{g} / \mathrm{L}$. This value is reduced to $0.75 \mu \mathrm{g} / \mathrm{L}$ with the CFME/p-NiTSPc. This results show that modification with p-NiTSPc has increased sensor sensitivity and can be used for determination of MNP in natural waters.

\section{Acknowledgements}

Authors would like to thank International Science Program (ISP) for supporting financially this work through African Network of Electroanalytical Chemists (ANEC).

\section{References}

[1] FAO (2017) Pesticides Use. http://www.fao.org/faostat/en/\#data/RP

[2] Deo, R.P., Wang, J., Block, I., Mulchandani, A., Joshi, K.A., Trojanowicz, M., Scholz, F., Chen, W. and Lin, Y. (2005) Determination of Organophosphate Pesticides at a Carbon Nanotube/Organophosphorus Hydrolase Electrochemical Biosensor. Analytica Chimica Acta, 530, 185-189.

https://doi.org/10.1016/j.aca.2004.09.072

[3] Kumaravel, A. and Chandrasekaran, M. (2011) A Biocompatible Nano TiO2/Nafion Composite Modified Glassy Carbon Electrode for the Detection of Fenitrothion. Journal of Electroanalytical Chemistry, 650, 163-170.

https://doi.org/10.1016/j.jelechem.2010.10.013

[4] Geremedhin, W., Amare, M. and Admassie, S. (2013) Electrochemically Pretreated Glassy Carbon Electrode for Electrochemical Detection of Fenitrothion in Tap Water and Human Urine. Electrochimica Acta, 87, 749-755. https://doi.org/10.1016/j.electacta.2012.09.046

[5] Tapsoba, I. and Kabore, B. (2012) Electrochemical Monitoring of Methyl Parathion Degradation Based on Carbon Fiber Microelectrodes (CFME). International Journal of Biological and Chemical Science, 6, 864-870. https://doi.org/10.4314/ijbcs.v6i2.28

[6] Sbaï, M., Essis-Tome, H., Gombert, U., Breton, T. and Pontié, M. (2007) Electrochemical Stripping Analysis of Methyl-Parathion (MPT) Using Carbon Fiber Microelectrodes (CFME) Modified with Combinations of Poly-NiTSPc and Nafion ${ }^{\otimes}$ films. Sensors and Actuators B Chemical, 124, 368-375. https://doi.org/10.1016/j.snb.2006.12.051

[7] Tapsoba, I., Bourhis, S., Feng, T. and Pontié, M. (2009) Sensitive and Selective Electrochemical Analysis of Methyl-parathion (MPT) and 4-Nitrophenol (PNP) by a New Type p-NiTSPc/p-PPD Coated Carbon Fiber Microelectrode (CFME). Electroanalysis, 21, 1167-1176. https://doi.org/10.1002/elan.200804529

[8] Pontié, M., Thouand, G., DeNardi, F., Tapsoba, I. and Lherbette, S. (2011) Antipassivating Electrochemical Process of Glassy Carbon Electrode (GCE) Dedicated to the Oxidation of Nitrophenol Compounds. Electroanalysis, 23, 1579-1584. https://doi.org/10.1002/elan.201100082

[9] Simões, F.R., de Toledo, R.A., Rodrigues, J.L. and Vaz, C.M.P. (2009) Direct Electroanalytical Determination of Methylparathion in Solution Extracted from Soil. International Journal of Environnemental Analytical Chemistry, 89, 95-104. 
https://doi.org/10.1080/03067310802478252

[10] Tapsoba, I., Paré, S., Toé, A., Kaboré, B., Koulibaly, B. and Bonzi-Coulibaly, Y. (2013) SWV Determination of Glyphosate in Burkina Faso Soils Using Carbon Fiber Microelectrode. International Journal of Biological and Chemical Science, 6, 2211-2220. https://doi.org/10.4314/ijbcs.v6i5.27

[11] Mohammadzadeh Kakhki, R. (2014) A Review to Recent Developments in Modification of Carbon Fiber Electrodes. Arabian Journal of Chemistry.

[12] Pontié, M., Sikpo, L., Thouand, G., Lahan, R., Tapsoba, I., Mallet, R. and Feng, T. (2011) Direct Electroanalysis of p-Nitrophenol (PNP) in Estuarine and Surface Waters by a High Sensitive Type C/p-NiTSPc Coating Carbon Fiber Microelectrode (CFME). Electroanalysis, 23, 433-441. https://doi.org/10.1002/elan.201000384

[13] Budai, D. (2010) Carbon Fiber-Based Microelectrodes and Microbiosensors. In: Somerset, V.S., Ed., Intelligent and Biosensors, 269-288. https://doi.org/10.5772/7158

[14] Pontie, M., Lecture, H. and Bedioui, F. (1999) Improvement in the Performance of a Nickel Complex-Based Electrochemical Sensor for the Detection of Nitric Oxide in Solution. Sensors and Actuators B Chemical, 56, 1-5.

[15] Moraes, F.C., Tanimoto, S.T., Salazar-Banda, G.R., Machado, S.A.S. and Mascaro, L.H. (2009) A New Indirect Electroanalytical Method to Monitor the Contamination of Natural Waters with 4-Nitrophenol using Multiwall Carbon Nanotubes. Electroanalysis, 21, 1091-1098. https://doi.org/10.1002/elan.200804522

[16] Tapsoba, I. (2004) Etude mécanistique et cinétique des imidates $\mathrm{N}$-fonctionnalisés par voie électrochimique: Application à la synthèse d'hétérocycles oxa-azotés et thiaza-azotés. [Electrochemical Mechanistic and Kinetic Studies of N-Functionalized Imidates: Application to Oxa-Nitrogenated and Thiaza-Nitrogenated Heterocycles Synthesis.] PhD Chemistry, University of Tunis El Manar, Tunisia.

[17] Ordaz, A.A., Bedioui, F. and Grandos, S.G. (1998) Electroformacion de peliculas de macrocomplejos de niquel. Aplicacion a la electrocatalisis de la oxidacion de fenoles. [Electrochemical Formation of Nickel Macrocyclic Complex-Based Films: Application to the Electrocatalysis of the Oxidation of Phenol Derivatives.] Boletin de la Sociedad Chilena de Quimica, 43, 375-390. 